\title{
Stratigraphic vs structural contacts in a late orogenic basin: the case of the Tertiary Piedmont Basin in the Sassello area (Ligurian Alps, Italy)
}

\author{
Laura Federico, Laura Crispini, Gian Mario Dabove, Michele Piazza \& \\ Giovanni Capponi
}

To cite this article: Laura Federico, Laura Crispini, Gian Mario Dabove, Michele Piazza \& Giovanni Capponi (2015): Stratigraphic vs structural contacts in a late orogenic basin: the case of the Tertiary Piedmont Basin in the Sassello area (Ligurian Alps, Italy), Journal of Maps, DOI: 10.1080/17445647.2015.1100561

To link to this article: http://dx.doi.org/10.1080/17445647.2015.1100561

View supplementary material $₫$

Published online: 19 Oct 2015.

Submit your article to this journal $\widetilde{ }$

Џ Article views: 5

Q View related articles ¿

View Crossmark data $₫$ 


\title{
Stratigraphic vs structural contacts in a late orogenic basin: the case of the Tertiary Piedmont Basin in the Sassello area (Ligurian Alps, Italy)
}

\author{
Laura Federico, Laura Crispini, Gian Mario Dabove, Michele Piazza and Giovanni Capponi \\ Dipartimento di Scienze della Terra, dell'Ambiente e della Vita, Università degli Studi di Genova, Corso Europa 26, Genova 16132, Italy
}

This geological map (1:10.000 scale) of the 'Sassello Basin' remnant covers an area of about 33.4 $\mathrm{km}^{2}$ of Liguria (NW Italy); it highlights the occurrence of two main types of contacts between the sediments of the Tertiary Piedmont Basin and the metamorphic substratum (Voltri Unit): (i) stratigraphic and (ii) structural (thrust or steeply dipping faults). (i) Stratigraphic contacts are represented by the main transgressive surface and the nonconformity between the metamorphic rocks of the substratum and the subaerial deposits. They are locally folded and occur along the steeply dipping short limbs of asymmetric folds related to the late-alpine/ apennine tectonics. (ii) Structural contacts are related to the late-alpine/apennine tectonics (thrust faults) or (mostly) to Plio-Quaternary extensional/transtensional faulting.
ARTICLE HISTORY

Received 18 May 2015

Revised 21 September 2015

Accepted 23 September 2015

KEYWORDS

Tertiary Piedmont Basin; stratigraphic contact; thrust tectonics; geological mapping

\section{Introduction}

This work deals with the Sassello basin-remnant outcropping in the central Ligurian Alps (central Liguria, northwestern Italy). The study area represents a triangular-shaped outcrop of the Tertiary Piedmont Basin (TPB) of about $11 \mathrm{~km}^{2}$. We have recently updated the geological map of the area, mapping the 212 'Spigno Monferrato' Quadrangle (CGR - Regione Liguria cartographic project; Capponi et al., 2013) and collected new stratigraphic and structural data.

The TPB is a syn-tectonic Neoalpine-Apennine basin (i.e. its evolution is coeval with the Neoalpine and Apenninc deformation events), filled by an upper Eocene - upper Miocene sedimentary succession, recording both Oligo-miocene late-alpine/apennine deformation events (e.g. Mosca, Polino, Rogledi, \& Rossi, 2009; Spagnolo, Crispini, \& Capponi, 2007) and Pliocene tectonics linked to the opening of the Ligurian Sea (e.g. Marini, 1984). The result is that most of the outcrops of the TPB rocks in Liguria are erosional remnants of a once much more continuous sedimentary cover. The Sassello area is one of these remnants, in which both primary contacts with the metamorphic substratum (Voltri Unit) and tectonically reworked contacts are preserved.

The geological map is accompanied by two crosssections and a map of the types of TPB-substratum contacts, which summarizes our interpretation of the relationships between the sedimentary rocks and their metamorphic substratum.

The aims of this paper are to (i) describe different types of geological contacts between the TPB sedimentary rocks and its metamorphic substratum, in the Sassello area, with the support of an original 1:10,000 geological map; (ii) discuss the relevance of the occurrence of primary and reworked contacts in a late-orogenic basin; and (iii) discuss the tectonic and regional significance of such situations in the framework of the geodynamic evolution of the Ligurian Alps.

\section{Geological setting}

The study area is located at the eastern termination of the Western Alps, that is, the Ligurian Alps (Figure 1) and is characterized by: (i) a metamorphic substratum belonging to the Ligurian-Piemontese units, and (ii) an upper Eocene-upper Miocene sedimentary succession of the TPB. In the following we briefly summarize the distinctive features of both the substratum and the sedimentary succession as described in literature.

\subsection{The substratum}

The substratum is made up of the Voltri tectonometamorphic Unit (Capponi et al., 2008; Capponi, Crispini, Federico, \& Malatesta, in press) (Figure 1) that is composed of metamorphic ophiolitic rocks with metasediments and slices of subcontinental lithospheric mantle (Chiesa et al., 1975; Rampone, Romairone, Abouchami, Piccardo, \& Hofmann, 2005). Meta-ophiolites correspond to serpentinite, metagabbro and metabasite, associated with calcschist, minor mica- and quartzschist; mantle rocks encompass lherzolite and harzburgite with minor pyroxenite and dunite (see Main Map).

The Voltri Unit attained eclogite facies metamorphic peak conditions during subduction of the Ligurian-Piemontese ocean (e.g. Bocchio, 1995; Ernst, 

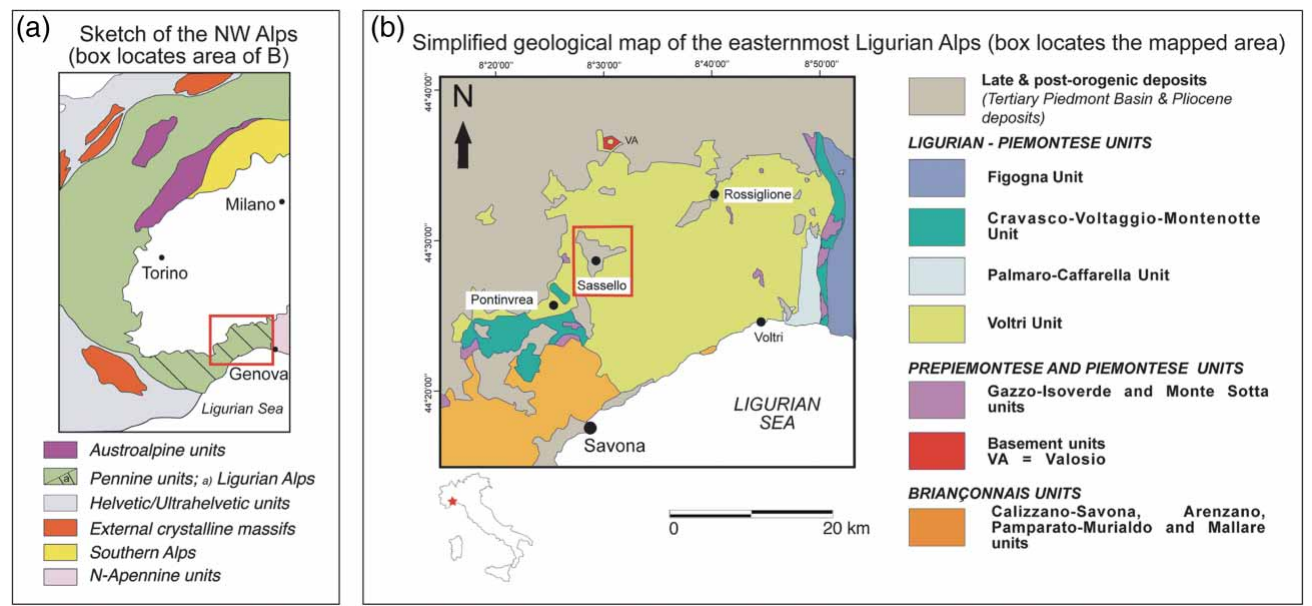

Figure 1. Geological setting of the study area.

1976) and was later re-equilibrated in greenschist facies metamorphic conditions.

\subsection{The Tertiary Piedmont Basin}

The TPB is a late- to post-orogenic basin that has an inner position with respect to the arcuate belt of the Western and Ligurian Alps (Capponi, Crispini, Federico, Piazza, \& Fabbri, 2009; Capponi, Crispini, Piazza, \& Amandola, 2001; Gelati \& Gnaccolini, 1988; Giglia, Capponi, Crispini, \& Piazza, 1996; Mutti et al., 1995). The basin fill unconformably overlies the collisional stack of tectonic units resulting from the main alpine orogenic deformation phases (Paleocene-Eocene; Federico, Capponi, Crispini, Scambelluri, \& Villa, 2005 with references therein). The Oligo-miocene late-alpine/apennine tectonics, related to the Corsica - Sardinia block rotation (e.g. Capponi \& Crispini, 2002; Capponi \& Giammarino, 1982; Mosca et al., 2009; Spagnolo et al., 2007), caused the top-to the E-NE back-thrusting and back-folding of the Ligurian Alps, with reworking of part of the original stratigraphic contacts. Such tectonic phase caused local uplift and the subsequent intense erosion of the TPB rocks, later dissected by the Pliocene mainly extensional/ transtensional fault tectonics, linked to the opening of the Ligurian Sea (e.g. Marini, 1984).

The depositional history of the TPB was controlled by tectonic and eustatic events (Capponi et al., 2001, 2009; Gelati \& Gnaccolini, 1988; Ghibaudo, Massari, \& Chiambretti, 2014; Ghibaudo, Massari, Chiambretti, \& d'Atri, 2014; Giglia et al., 1996; Mutti et al., 1995).

The basin was filled with non-marine to marine sediments, spanning in age from the upper Eocene to the upper Miocene. The early stage of sedimentation of TPB records a subaerial and transgressive phase characterized by the deposition of alluvial fan and fan-delta siliciclastic conglomerates and sandstones, marine shallow-water coarse to fine grained siliciclastic sediments and local reef limestones (Bonci, Vannucci, Tacchino, \& Piazza, 2011; Capponi et al., 2013, and references therein; Gelati \& Gnaccolini, 1988; Gelati et al., 2010; Lorenz, 1969; Ghibaudo, Massari, \& Chiambretti, 2014; Ghibaudo, Massari, Chiambretti, \& d'Atri, 2014; Mutti et al., 1995; Quaranta, Piazza, \& Vannucci, 2009; Turco, Duranti, Iaccarino, \& Villa, 1994).

The lithostratigraphic section of the Sassello area (upper Eocene-Oligocene; Figure 2) is described in the following section (according to Capponi et al., 2013, and references therein).

Sedimentation starts with fine to very coarse siliciclastic alluvial fan, river plain and slope and scree deposits that grade upwards to fan-delta sandstone and conglomerate (Costa di Cravara breccia - CRA and basal part of the Molare Formation comprising continental conglomerates and sandstones - MOR, Upper Eocene-lower Oligocene, see Main Map). These laterally discontinuous bodies are overlain by littoral and sublittoral sediments, and by coral boundstones that, locally, rest directly on the metamorphic substratum (middle part of the Molare Formation MORt, Rupelian-middle Chattian). These transgressive facies are overlain by fine to medium sandstone, which grade to siltstone and marly siltstone (upper part of the Molare Formation - MORm, Upper Oligocene). MORm facies record a deepening phase that reached its maximum with the deposition of a succession of silty sandstone, siltstone and marl, interbedded with lenticular sandstone and conglomerate (Rocchetta Formation - RTM, Upper Oligocene-lower Miocene?).

\section{Structural setting}

The Voltri tectonometamorphic Unit is affected by greenschist facies tight to isoclinal transpositive folds $\left(D_{1}\right.$ and $D_{2}$ of Capponi \& Crispini, 2002; Crispini \& Frezzotti, 1998), and related schistosities whose superposition produced the regional composite fabric. 


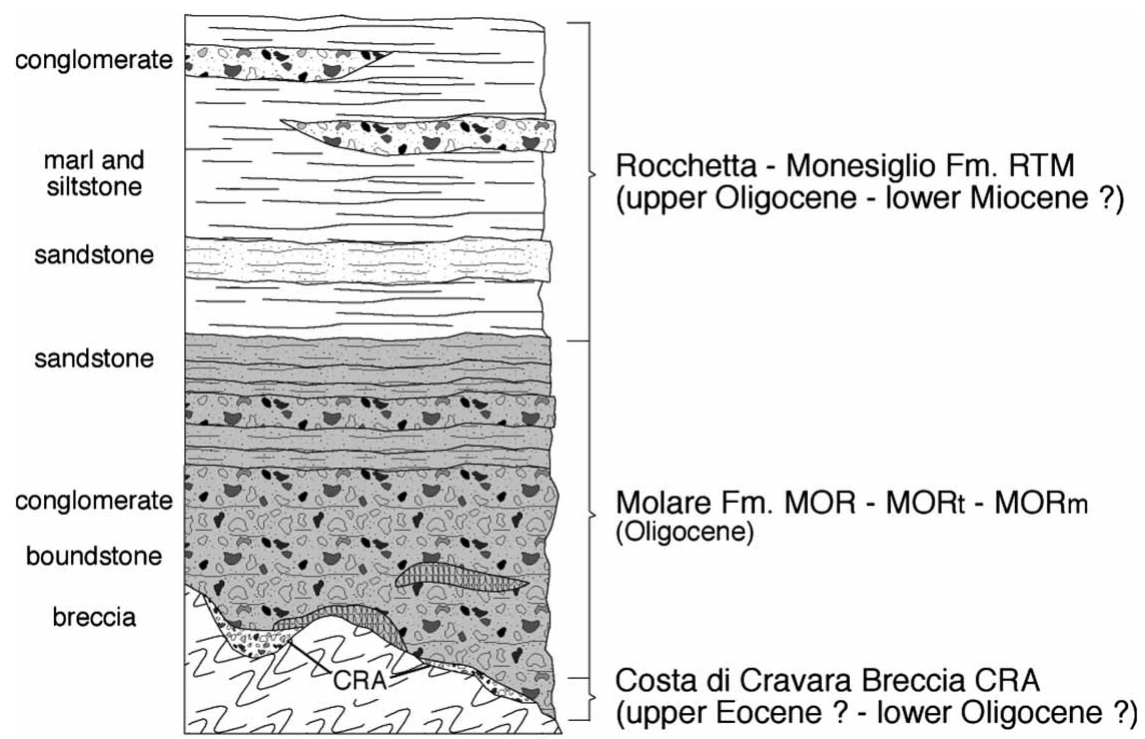

Figure 2. Stratigraphic column of the TPB in the Sassello area (not to scale).

Younger structures are gentle to open folds, developed in low greenschist facies metamorphic conditions $\left(D_{3}\right.$ of Capponi \& Crispini, 2002) and then non-metamorphic long-wavelength asymmetric folds and thrust faults that share the same top-to-the E-NE sense of shear $\left(\mathrm{D}_{4}\right.$ after Capponi \& Crispini, 2002). These structures affect both the substratum and the TPB succession (Bernini \& Zecca, 1990; Capponi \& Crispini, 2002; Capponi \& Giammarino, 1982; d'Atri, Piana, Tallone, Bodrato, \& Roz Gastaldi, 1997; Mosca et al., 2009; Pasquarè, 1968; Spagnolo et al., 2007) and are generally interpreted (Capponi \& Crispini, 2002; Spagnolo et al., 2007) as linked to the rotation of the Corsica-Sardinia block during Aquitanian - middle Miocene (Gattacceca et al., 2007; Maffione et al., 2008; Speranza et al., 2002).

Lastly, structures are mainly strike-slip and normal faults linked to the Plio-Quaternary tectonics (Fanucci, 1986; Marini, 1984).
The gulf of Genova progressively attained the present morphology during the late Miocene-Pliocene opening of the Northern Thyrrenian basin (Kastens et al., 1988, and references therein). Such a tectonic event was characterized by uplift of the Ligurian Alps and quick deepening of the Ligurian Sea (Fanucci, 1986; Lorenz, 1984).

The Ligurian coastal evolution was controlled by EW striking faults connected with N-S and NNW-SSEstriking faults that delineated graben/pull apart basins (Marini, 1984, and references therein); as this faulting controlled the Pliocene sedimentation along the Ligurian coast, their activity is constrained in age.

During Pleistocene time, normal, often listric, faults were active along the Ligurian Alps southern slope and the Ligurian coast and continental margin, and caused the uplift of the Ligurian coastal area and its northwards tilting, which in turn is responsible for the strong asymmetry between the gentle northern and the steep

\section{Stratigraphic contacts}

(a) Type 1a (Transgressive unconformity)

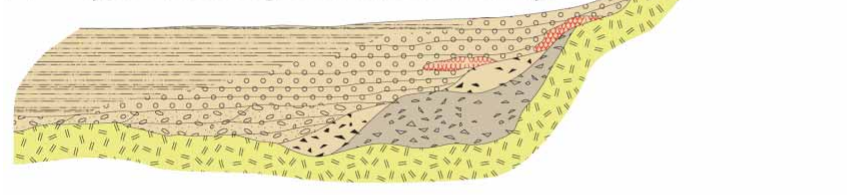

(b) Type 16 (Non-transgressive unconformity)

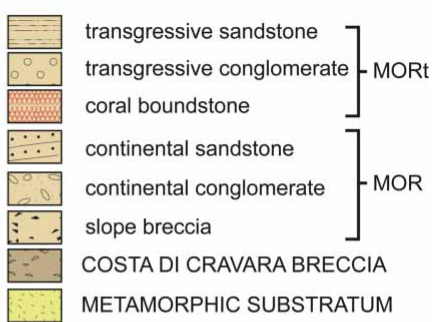

METAMORPHIC SUBSTRATUM

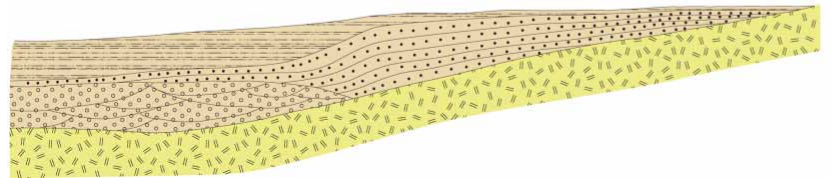

Figure 3. Stratigraphic contacts. Synthetic sketch summarizing the two different types of stratigraphic contacts occurring between the TPB sediments and the metamorphic substratum: (a) type 1a (Transgressive unconformity) and (b) type 1b (Non-transgressive unconformity). 


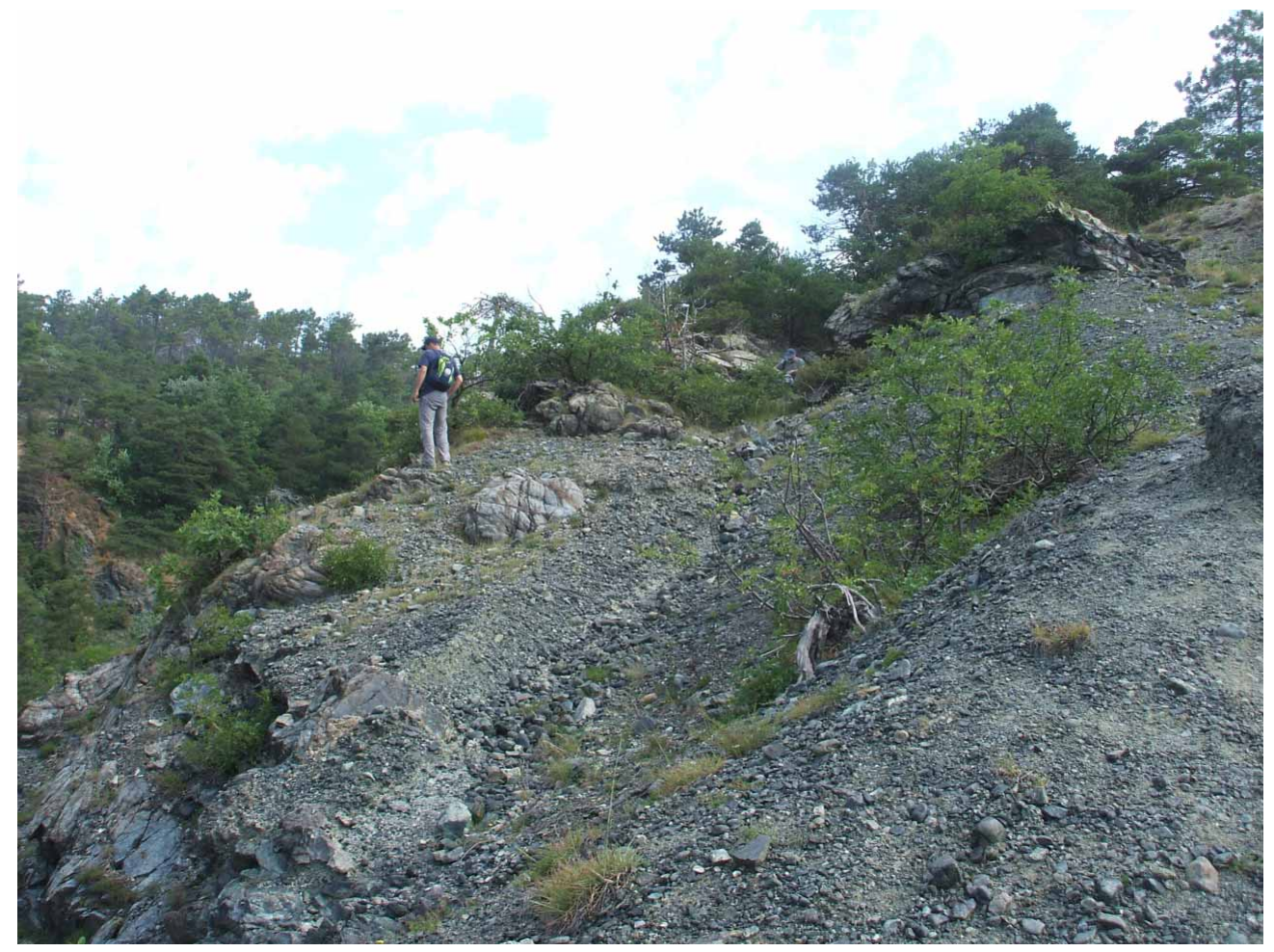

Figure 4. Field photograph showing an example of type 1a contact. In the lower left corner the metamorphic substratum is cut by sea action and in the upper right the weathered substratum surface.

southern slope of the Ligurian Alps (Fanucci, 1986; Fanucci, Giammarino, \& Tedeschi, 1980; Fanucci, Tedeschi, \& Vignolo, 1982; Lorenz, 1984).

\section{Field data - types of contacts}

In the mapped area (see Main Map) we observed different types of relations between the TPB sediments and their metamorphic substratum, and in particular: (1) stratigraphic contacts and (2) structural contacts.

\subsection{Stratigraphic contacts (Type 1)}

The Molare Fm. unconformably onlaps the metamorphic substratum (i.e. the Voltri Unit), recording a progressive transgression of shallow-marine facies (i. e. MORt), mainly represented by conglomerates, hybrid arenites and local coral boundstones. Locally, non-marine siliciclastic deposits (i.e.: MOR, but also CRA; conglomerate, sandstone, mudrock and breccia) occur on the metamorphic rocks and indicate that the substratum was exposed and affected by weathering, erosion and deposition in subaerial conditions. Erosional, depositional and coral growth processes on the paleo-topography produced a composite arrangement of small-scale subaerial and transgressive facies.

These features suggest that the upper Eocene-lower Oligocene paleo-topography comprised a series of (probably) structurally controlled highs, along which the reef community developed, and lows filled by clastic sediments. Therefore, the marine transgression took place onto a substratum characterized by a rugged surface and the facies heterogeneity is the result of depositional processes interacting with the substratum topography.

\subsubsection{Transgressive unconformity (Type 1a)}

The transgressive event took place onto a rugged surface that is evidenced by the coral colonization that developed on an irregular, smooth and steep surface cut in the serpentinites by the sea action (Figures 3(a) and (b) and 4). The deposition of poorly sorted siliciclastic sediments occurred amongst the coral
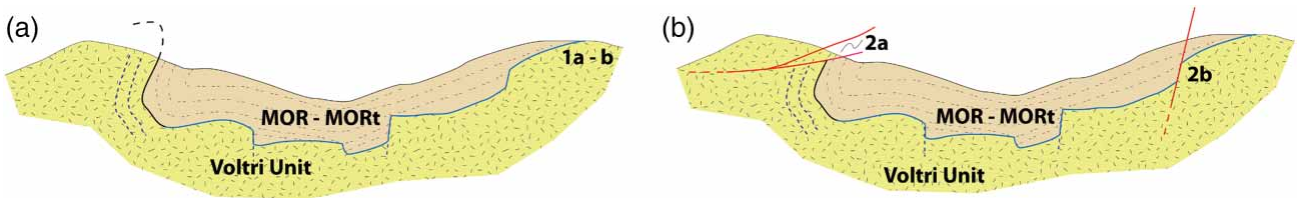

Figure 5. Schematic section (roughly W-E) across the Sassello area showing: (a) types of contacts 1a-b (stratigraphic contacts), locally folded (i.e. to the west); (b) type $2 a-b$ contact (tectonic contacts). 

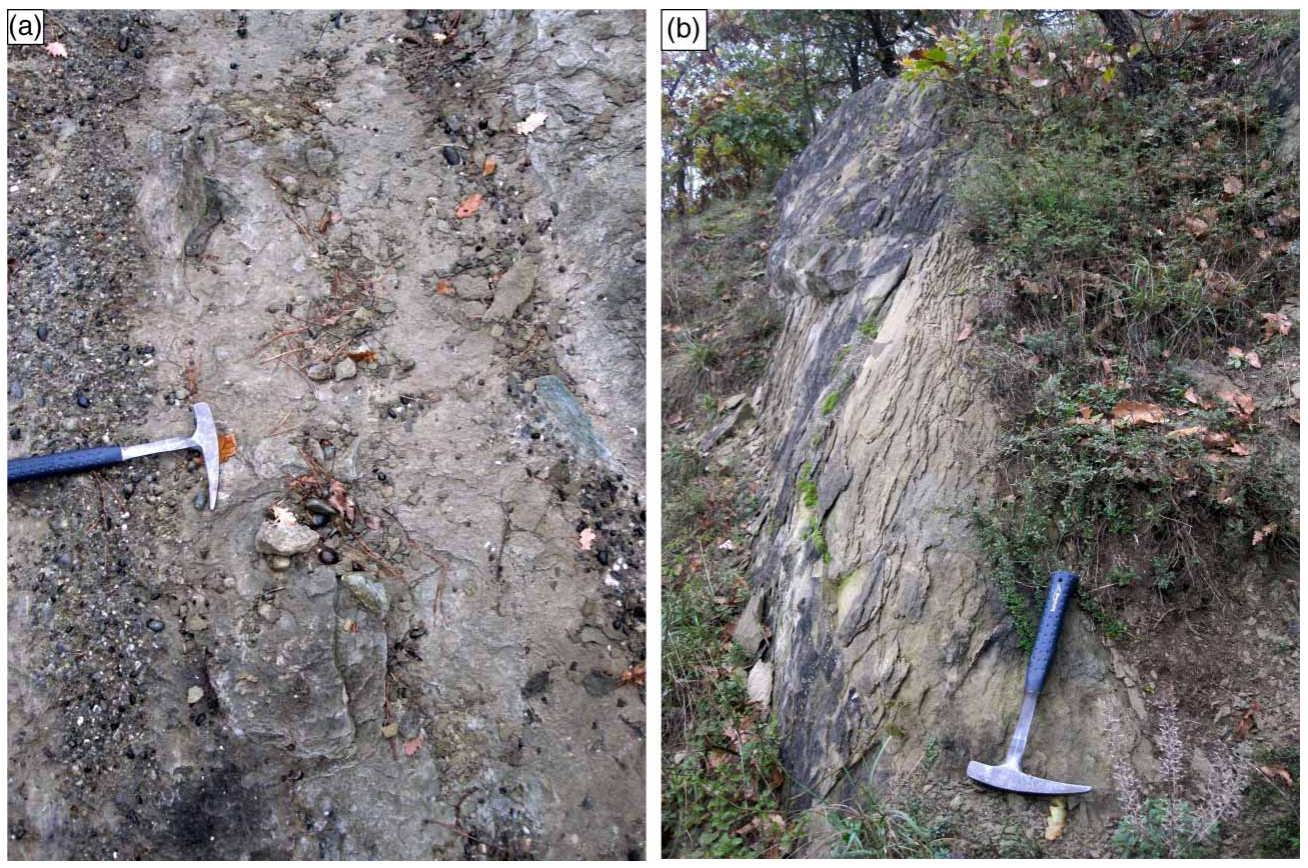

Figure 6. Field photographs showing the steeply dipping bedding surfaces in the Molare Formation where stratigraphic contacts are folded; (a) horizontal cut and (b) W-E section.

settlements. Such sediments were supplied by stream activity and were coarse to very coarse grained; they formed an irregular seabottom, on which coral colonization also developed once again.

Higher upslope, the serpentinites surface becomes weathered, rough and angular, testifying to a long subaerial exposure. Furthermore, the transgressed substratum can be represented also by siliciclastic, non-marine deposits (Figure 3(b)). This basal level and the upslope surface is covered by lenticular and clinostratified conglomerate and minor sandstone beds; this depositional event suddenly suffocated reef growth (e.g. see Figure 4).

\subsubsection{Non-transgressive unconformity (Type 1b)}

The weathered, rough and angular metamorphic substratum is unconformably covered by discontinuous and unevenly distributed, non-marine sedimentary deposits, often confined in more or less incised lows. These deposits (e.g. north of Rio Colla) are composed of conglomerate and sandstone, and minor breccia and mudrock, that are the result of alluvial fan, river plain and lacustrine/palustrine deposition. Such deposits can be covered by both bioconstructed and siliciclastic transgressive deposits (Figure 3(a)).

In places, stratigraphic contacts of both Type 1a and $1 \mathrm{~b}$ and bedding in the Molare Formation (mostly at the western edge of the Sassello Basin-remnant; Figure 5, see the map of the types of contacts) are steeply dipping (e.g. south of Monte Savino; Figure 6(a) and (b)), locally overturned (e.g. on the eastern slope of Monte Savino). This occurs at the short limbs of asymmetric, long-wavelength open folds, with subhorizontal, N-S trending axes (see the geological map and the map of the types of contacts). These structures are characterized by axial plane surfaces steeply to moderately dipping to the $\mathrm{W}$ and vergence toward the $\mathrm{E}$; the contacts along the short limbs of the asymmetric anticlines therefore result in transitions from the metamorphic substratum to the transgressive lithofacies (MORt) and the marine lithofacies (MORm) of the Molare Fm. that, being steeply dipping, in map view appear as NNW-SSE-striking stripes (see the map of the types of contacts).

\subsection{Structural contacts (Type 2)}

\subsubsection{Contacts along thrust faults (Type 2a)}

Locally, contacts between the metamorphic substratum and the TPB sediments occur along top-to-the $\mathrm{E}$ thrust faults that are in kinematic agreement with the folds described above. They occur mostly at the western boundary of the Sassello basin (see the map of the types of contacts and Figure 5(b)), but also locally crop out to the NE of the basin, across the valley of the Gallaretto stream. The hanging wall is usually represented by the metamorphic substratum (Figure 7(a)-(c)). Locally, along such contacts (e.g. in the localities Case Ramorino; NE of Palazzo Garbarini; $\mathrm{N}$ of Rocca Colombi) there is an unexpected superposition of continental or transgressive lithofacies (MOR or MORt) onto the marine lithofacies (MORm) of the Molare Fm.

Both folds and thrusts pertain to the back-folding and back-thrusting event of the Ligurian Alps, Aquitanian - lower Burdigalian in age, recognized both at the eastern side of the Voltri massif (Capponi et al., 2009) and in the Sassello area (Capponi et al., 2001). Different 

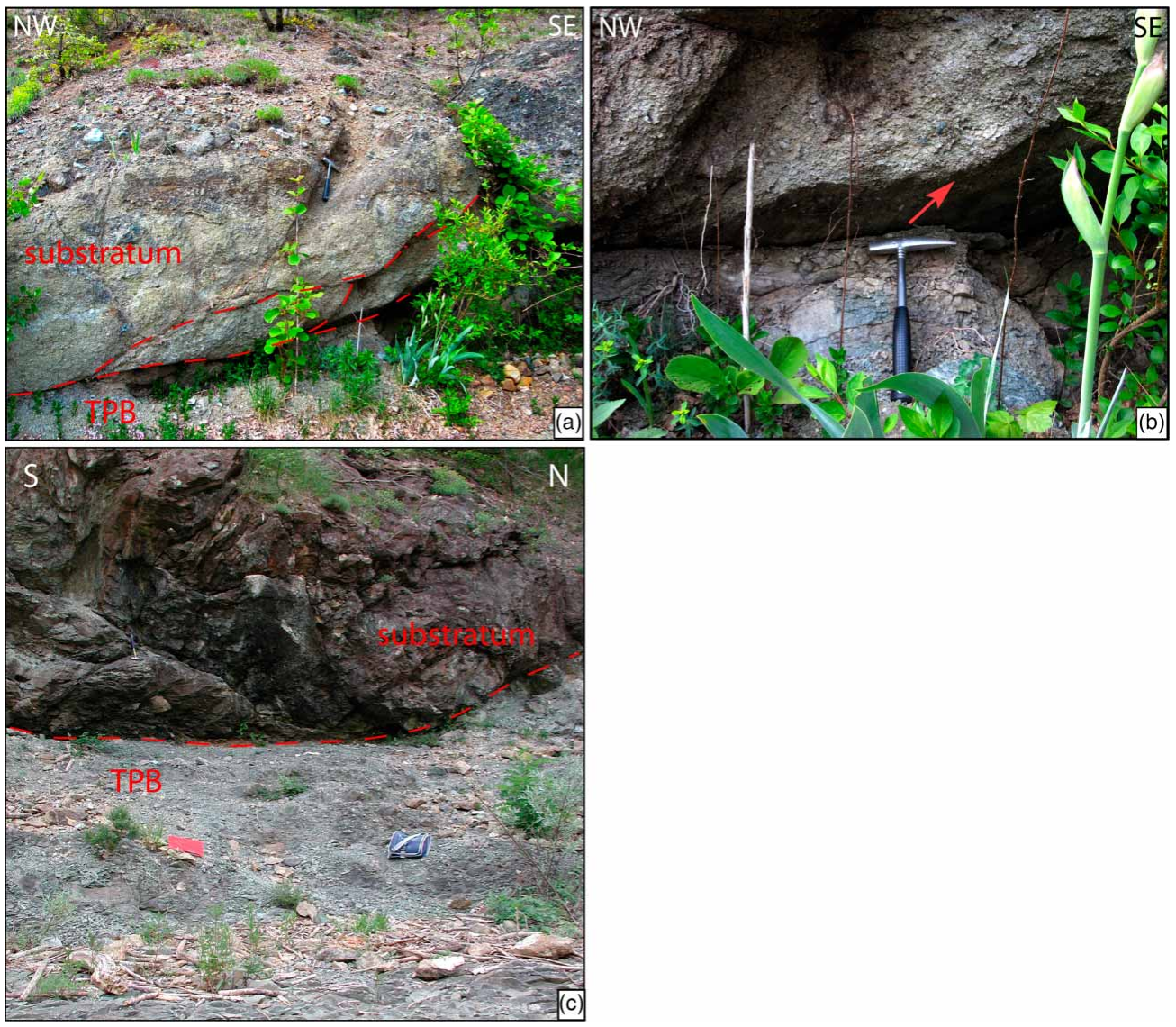

Figure 7. (a) Field photograph showing a thrust fault at the contact between TPB conglomerate of the Molare Fm. (footwall) and cataclastic serpentinite (hanging wall). Cobbles on top of the hanging wall are Quaternary cover. Sense of shear is top to SE; (b) detail of the field photograph in (a) showing direction and sense of movement of the hanging wall (red arrow); (c) field photograph showing a thrust fault between TPB sandstone of the Molare Fm. (footwall) and cataclastic serpentinite (hanging wall); this structure has been already been described by Capponi et al. (2001).

thrust/fold segments are separated by ENE-WSWstriking tear faults (see the geological map and the map of the types of contacts).

\subsubsection{Contacts along steep faults (Type 2b)}

Contacts along steep faults are frequent in the Sassello area. Steeply dipping faults occur in two sets:

- faults associated to thrust faults as tear faults, mainly with a strike-slip sinistral sense of shear: this is particularly common in the western portion of the study area. Moreover, rocks of the TPB in the eastern part of the study area (i.e. from the Prà Vallarino locality to the Rio Viorina) are involved in a roughly E-W strike-slip fault zone kinematically linked to the Aquitanian - lower Burdigalian event (Federico, Crispini, Vigo, \& Capponi, 2014).

- Faults developed during a younger, Plio-Quaternary tectonic event, with main ENE-WSW to NE-SW strike and both strike-slip dextral and normal sense of shear (Federico et al., 2014, and references therein). Such a tectonic event also reactivated some of the faults of the previous event (for instance, along the Rio Viorina), as normal or strike-slip faults.

\section{Discussion}

In the Sassello area (central Liguria, NW Alps), the new geological mapping highlighted the occurrence of two main types of contacts between the sedimentary rocks of the TPB and the metamorphic substratum of the Voltri Unit: 1 - stratigraphic and 2 structural, either along thrust (2a) or steeply dipping faults (2b).

The basal surface of the Molare Fm. (Type 1) is defined by two different types of contacts: (1a) the transgressive surface that can be drawn only by taking into account both the coral limestone and the siliciclastic marine deposits (i.e. MORt); (1b) the surface between the metamorphic rocks of the substratum and the non-marine siliciclatic deposits (i.e. MOR). The first one is characterized by the marine onlap on a rough, locally steep, paleo-topographic surface (i.e. eroded metamorphic substratum and non-marine deposits), the second one reflects the confinement of the sedimentary bodies in lows; therefore, these surfaces are mapped in apparent disagreement with the basic rules of geological mapping (i.e. the ' $\mathrm{V}$ ' rules). This mapping approach must be applied to the whole area regarding the basal Molare Formation 
(transgressive and subaerial facies) and the Cravara Breccia basal nonconformity.

The roughness of the pre-depositional paleo-topographic surface is the consequence of pre-depositional tectonic activity affecting the metamorphic rocks, followed by long subaerial exposure to strong weathering and erosion. It should be noted that no evidence of synsedimentary tectonics has been observed in the field.

The stratigraphic contacts are locally folded by asymmetric, E-vergent folds: in places contacts occur along the steeply dipping short limbs. These folds locally evolve into thrust faults (Type 2a). These types of contacts are a consequence of the Aquitanian-Burdigalian late-alpine/apennine tectonics, which caused the back-folding and back-thrusting of the alpine units toward E-NE. Due to this back-thrusting, the TPB underwent local uplift and evolved as a piggy-back basin (Capponi et al., 2001, 2009, and references therein). In the study area, thrust faults are associated to a roughly E-W striking sinistral strikeslip zone (Federico et al., 2014).

The evolution of the TPB in the Sassello area is therefore much more complex with respect to a simple post-orogenic basin and represents an appropriate case study for all the basins involved in the late tectonic phases of an orogenic belt.

Additional complexity is supplied by the Pliocene evolution: during the Pliocene, a new set of mainly extensional/transtensional faults developed, or previous faults with appropriate orientation were reactivated, in the context of the opening of the Ligurian Sea (e.g. Marini, 1984). This caused uplift of the metamorphic bedrock and erosion, so that most outcrops of TPB rocks in Liguria are erosional remnants of a once much more continuous sedimentary cover; the Sassello Basin is one of the largest in the Ligurian sector. The present-day segmentation of TPB outcrops is consequently linked to the post-Oligocene tectonic evolution. Most of the contacts along steeply dipping faults (Type 2b) are related to this phase of Pliocene to Quaternary tectonics.

\section{Conclusions}

The Sassello area (central Liguria, NW Alps) is characterized by the occurrence of two types of contacts between the sedimentary rocks of the TPB and the metamorphic substratum of the Voltri Unit: 1 - stratigraphic; 2 - structural, either along thrust (2a) or steeply dipping faults (2b).

The reworking of the stratigraphic contacts by folds and faults is the result of the involvement of the TPB in the late orogenic tectonic phases of the Ligurian Alps. The Pliocene tectonic evolution added complexity, causing the present-day segmentation of the TPB outcrops.
The case study reveals the complexity of the evolution of the sedimentary basins involved in the late tectonic phases of an orogenic belt.

\section{Acknowledgements}

Thanks are due to Eugenio Poggi, Silvia Torchio and Andrea Vigo for field assistance during geological mapping. This paper has greatly profited from critical reading by C. Di Celma, M. Shand and G. Ghibaudo.

\section{Disclosure statement}

No potential conflict of interest was reported by the authors.

\section{Funding}

Funding was provided by the COFIN-MIUR 2010-2011 project entitled 'Birth and death of oceanic basins: geodynamic processes from rifting to continental collision in Mediterranean and circum-Mediterranean orogens' (National Coordinator G. Capponi) and by Ateneo funds from the University of Genova.

Base data come from the geological mapping project 212 'Spigno Monferrato' quadrangle, funded by the Regione Liguria (Project Manager Gianna Gorziglia), that is gratefully acknowledged.

\section{Software}

Adobe Illustrator CS4 and Avenza MaPublisher 8.3.3 were used to produce the map.

\section{References}

Bernini, M., \& Zecca, M. (1990). Le deformazioni nella Formazione di Molare e Rocchettta (OligoceneeMiocene inferiore) della regione di Mioglia (SV) (Margine sud del Bacino Terziario Piemontese). Atti Ticinensi di Scienze della Terra, 33, 1-10.

Bocchio, R. (1995). Chemical variations in clinopyroxenes and garnet from eclogites of the Vara Valley (Voltri Group), Italy. European Journal of Mineralogy, 7, 103-118.

Bonci, M. C., Vannucci, G., Tacchino, S., \& Piazza, M. (2011). Oligocene fossil leaves of the Perrando Collection: History, preservation, and paleoclimatic meaning. Bollettino della Società Paleontologica Italiana, 50, 145-164. doi:10.4435/BSPI.2011.14

Capponi, G., \& Crispini, L. (2002). Structural and metamorphic signature of alpine tectonics in the Voltri Massif (Ligurian Alps, northwestern Italy). Eclogae Geologicae Helvetiae, 95, 31-42. doi:10.5169/seals-168944

Capponi, G., Crispini, L., con la collaborazione di Bonci, M. C., Cabella, R., Cavallo, C., Cortesogno, L., ... Zuccolini, M. (2008). Note Illustrative del Foglio 213 - 230 "Genova" della Carta Geologica d'Italia alla scala 1:50.000. Firenze: Apat - Regione Liguria.

Capponi, G., Crispini, L., Federico, L., con contributi di Cabella, R., Faccini, F., Ferraris, F., ... Vetuschi Zuccolini, M. (2013). Note Illustrative al Foglio 212 "Spigno Monferrato" della Carta Geologica Regionale 
della Liguria. Genova: Regione Liguria. http://www. cartografia.regione.liguria.it/apriFoglia.asp?itemID $=30208$ \&fogliaID=1575\&label=Carta20Geologica20Regionale202 8CGR2920sc.201:1000020riferita20al20Foglio2021220Spig no20Monferrato20-20sc.201:50000

Capponi, G., Crispini, L., Federico, L., \& Malatesta, C. (in press). Geology at the Ligurian knot: A review of the tectonic units. Italian Journal of Geosciences.

Capponi, G., Crispini, L., Federico, L., Piazza, M., \& Fabbri, B. (2009). Late alpine tectonics in the Ligurian Alps: Constraints from the tertiary piedmont basin conglomerates. Geological Journal, 44, 211-224. doi:10.1002/gj. 1140

Capponi, G., Crispini, L., Piazza, M., \& Amandola, L. (2001). Field constraints to the Mid-Tertiary kinematics of the Ligurian Alps. Ofioliti, 26, 409-416.

Capponi, G., \& Giammarino, S. (1982). L'affioramento oligocenico del Rio Siria (Bacino di Santa Giustina, provincia di Savona), nel quadro dei movimenti tardivi della falda di Montenotte. Atti della Società Toscana di Scienze Naturali, A, 89, 101-113.

Chiesa, S., Cortesogno, L., Forcella, F., Galli, M., Messiga, B., Pasquarè, G., \& Rossi, P. M. (1975). Assetto strutturale ed interpretazione geodinamica del Gruppo di Voltri. Bollettino della Società Geologica Italiana, 94, 555-582.

Crispini, L., \& Frezzotti, M. L. (1998). Fluid inclusion evidence for progressive folding during decompression in metasediments of the Voltri Group (Western Alps, Italy). Journal of Structural Geology, 20, 1733-1746. doi:10.1016/S0191-8141(98)00087-X

d'Atri, A., Piana, F., Tallone, S., Bodrato, G., \& Roz Gastaldi, M. (1997). Tettonica Oligo-Miocenica nell'alto Monferrato (Bacino Terziario Piemontese) e nel settore nord-occidentale del Gruppo di Voltri (Acqui Terme e Cassinelle, AL). Atti Ticinensi di Scienze della Terra, (Ser. Spec.) 5, 85-100.

Ernst, W. G. (1976). Mineral chemistry of eclogites and related rocks from the Voltri Group, Western Liguria, Italy. Schweizerische Mineralogische und Petrographische Mitteilungen, 56, 293-343.

Fanucci, F. (1986). Evolution stratigraphique de la région du golfe de Gênes depuis l'Eocène Supérieur. Memorie della Società Geologica Italiana, 36, 19-30.

Fanucci, F., Giammarino, S., \& Tedeschi, D. (1980). Il Pliocene della costa e del margine continentale dell'Appennino Ligure in rapporto alla neotettonica. Memorie della Società Geologica Italiana, 21, 259-265.

Fanucci, F., Tedeschi, D., \& Vignolo, A. (1982). Nuovi dati di neotettonica rilevati sul foglio 82 Genova. Progetto Finalizzato Geodinamica, Contributi preliminari alla realizzazione della carta neotettonica d'Italia, Pubbl, 356, 1293-1303.

Federico, L., Capponi, G., Crispini, L., Scambelluri, M., \& Villa, I. M. (2005). 39Ar/40Ar dating of high-pressure rocks from the Ligurian Alps: Evidence for a continuous subduction exhumation cycle. Earth and Planetary Science Letters, 240, 668-680. doi: 10.1016/j.epsl.2005.09. 062

Federico, L., Crispini, L., Vigo, A., \& Capponi, G. (2014). Unravelling polyphase brittle tectonics through multisoftware fault-slip analysis: The case of the Voltri Unit, Western Alps (Italy). Journal of Structural Geology, 68, 175-193. doi:10.1016/j.jsg.2014.09.011

Gattacceca, J., Deino, A., Rizzo, R., Jones, D. S., Henry, B., Beaudoin, B., \& Vadeboin, F. (2007). Miocene rotation of Sardinia: New paleomagnetic and geochronological constraints and geodynamic implications. Earth and Planetary Sciences Letters, 258, 359-377.

Gelati, R., \& Gnaccolini, M. (1988). Sequenze deposizionali in un bacino episuturale, nella zona di raccordo tra Alpi ed Appennino Settentrionale. Atti Ticinensi di Scienze della Terra, 31, 340-350.

Gelati, R., Gnaccolini, M., Polino, R., Mosca, P., Piana, F., Morelli, M., ... Ossella, L. (2010). Note Illustrative della Carta Geologica d'Italia alla scala 1:50.000, foglio 211 "Dego". Progetto CARG, Ispra - Arpa Piemonte.

Ghibaudo, G., Massari, F., \& Chiambretti, I. (2014). OligoMiocene tectono-sedimentary evolution of the Langhe sub-basin: from continental to basinal setting (Tertiary Piedmont Basin - Northwestern Italy). Journal of Mediterranean Earth Sciences, 6, 53-144. doi:10.3304/ JMES.2014.002

Ghibaudo, G., Massari, F., Chiambretti, I., \& d'Atri, A. (2014). Oligo-Miocene tectono-sedimentary evolution of the tertiary piedmont basin southern margin, Roccaverano area-Langhe Sub-basin (NW Italy). Journal of Mediterranean Earth Sciences, 6, 1-51. doi:10.3304/ JMES.2014.001

Giglia, G., Capponi, G., Crispini, L., \& Piazza, M. (1996). Dynamics and seismotectonics of the West-Alpine arc. Tectonophysics, 267, 143-175.

Kastens, K., Mascle, J., Auroux, C., Bonatti, E., Broglia, C., Channell, J., ... Torii, M. (1988). ODP Leg 107 in the Tyrrhenian Sea: Insights into passive margin and backarc basin evolution. Geological Society of America Bulletin, 100, 1140-1156. doi:10.1130/0016-7606(1988) $100<1140$ :OLITTS $>2.3$.CO;2

Lorenz, C. (1969). Contribution à l'étude stratigraphique de l'Oligocène et du Miocène inférieur des confins liguropiémontais (Italie). Atti dell'Istituto di Geologia dell'Università di Genova, 6, 253-888.

Lorenz, C. (1984). Evolution stratigraphique et structurale des Alpes Ligures depuis l'Eocène Superieur. Memorie della Società Geologica Italiana, 28, 211-228.

Maffione, M., Speranza, F., Faccenna, C., Cascella, A., Vignaroli, G., \& Sagnotti, L. (2008). A synchronous Alpine and Corsica-Sardinia rotation. Journal Geophysical Research, doi: 10.1029/2007JB005214

Marini, M. (1984). Le deformazioni fragili del Pliocene Ligure. Implicazioni nella geodinamica alpina. Memorie della Società Geologica Italiana, 29, 157-169.

Mosca, P., Polino, R., Rogledi, S., \& Rossi, M. (2009). New data for the kinematic interpretation of the AlpseApennines junction (Northwestern Italy). International Journal of Earth Sciences, 99, 833-849. doi:10.1007/s00531-009-0428-2

Mutti, E., Papani, L., Di Biase, D., Davoli, G., Mora, S., Segadelli, S., \& Tinterri, R. (1995). Il Bacino Terziario Epimesoalpino e le sue implicazioni sui rapporti tra Alpi ed Appennino. Memorie di Scienze Geologiche, 47, 217-244.

Pasquarè, G. (1968). La serie di Montenotte: un elemento alloctono sovrapposto al bacino Oligocenico di Santa Giustina (Alpi Liguri). Rivista Italiana di Paleontologia e Stratigrafia, 74, 1257-1273.

Quaranta, F., Piazza, M., \& Vannucci, G. (2009). Climatic and tectonic control on the distribution of the Oligocene reefs of Tertiary Piedmont Basin (NW Italy). Italian Journal of Geosciences, 128, 587-591. doi:10.3301/IJG. 2009.128.2.587

Rampone, E., Romairone, A., Abouchami, W., Piccardo, G. B., \& Hofmann, A. W. (2005). Chronology, petrology and isotope geochemistry of the Erro-Tobbio peridotites 
(Ligurian Alps, Italy): Records of Late Palaeozoic lithospheric extension. Journal of Petrology, 46, 799-827. doi:10.1093/petrology/egi001

Spagnolo, C., Crispini, L., \& Capponi, G. (2007). Late structural evolution in an accretionary wedge: Insights from the Voltri Massif (Ligurian Alps, Italy). Geodinamica Acta, 20, 21-35. doi:10.3166/ga.20.21-35

Speranza, F., Villa, I. M., Sagnotti, L., Florindo, F., Cosentino, D., Cipollari, P., \& Mattei, M., (2002). Age of the Corsica-
Sardinia rotation and Liguro-Provençal Basin spreading: New paleomagnetic and Ar/Ar evidence. Tectonophysics, 347, 231-251.

Turco, E., Duranti, D., Iaccarino, S., \& Villa, G. (1994). Relationships between foraminiferal biofacies and lithofacies in the Oligocene Molare Formation and Rigoroso Marl: preliminary results from the Piota River section (Tertiary Piedmont Basin, NW Italy). Giornale di Geologia, 3, 56, 101-117. 